811.163.41'367.622.16

811.163.41'367

https://doi.org/10.18485/sj.2017.22.1.30

БОРКО Н. КОВАЧЕВИТ

Универзитет у Београду

Филолошки факултет
Оригинални научни рад

Примљен: 24. 08. 2016.

Прихваћен: 15. 12. 2016.

\title{
О ГЛАГОЛСКИМ ИМЕНИЦАМА КОЈЕ СУ МОДИФИКОВАНЕ ПРИЛОГОМ У САВРЕМЕНОМ СРПСКОМ ЈЕЗИКУ**
}

У раду се говори о примерима у којима су глаголске именице модификоване прилозима. У питању су месни, временски и прилози за начин. Истраживање показује да се примери у којима су прилозима модификоване глаголске именице (долазак овде) суштински разликују од примера у којима су прилозима модификоване конкретне именице (кућа слијева). Само у случају модификације глаголских именица прилог директно модификује именицу. У случају конкретних именица, прилог је само репрезентант односне реченице, и директно модификује глагол који је центар те односне реченице.

Чињеница да се глаголске именице у српском језику могу модификовати и прилозима, а не само придевима, може се објаснити структурним приступом А. Алексиаду. Према овом приступу, за могућност употребе прилога уз глаголске именице одговорне су неке типично глаголске функционалне категорије у структури ових именица, као што су вид или стање.

Кључне речи: српски језик, прилог, глаголске именице, функционална категорија

\footnotetext{
*borko.kovacevic@fil.bg.ac.rs

** Рад је настао у оквиру пројекта Савремени српски језик: синтаксичка, семантичка $и$ прагматичка истраживања (бр. 178004) Филозофског факултета у Новом Саду и Филолошког факултета у Београду, који финансира Министарство науке Републике Србије.
} 


\section{УВОДНЕ НАПОМЕНЕ}

Опште је прихваћен став да су придеви и прилози комплементарни типови модификатора, у смислу да придеви модификују именице, а прилози глаголе. Постоје међутим примери који нарушавају тврдњу о комплементарности придева и прилога као модификатора. Ради се о примерима као што су долазак овамо, певање наглас и слични, у којима су именице модификоване прилозима, а не придевима, како би се то очекивало. Предмет овог рада јесу управо такви примери - глаголске именице уз које су употребљени прилози.

У домаћој литератури нема много радова који су се бавили овом тематиком. Свакако најзначајнији су радови М. Ковачевића (Ковачевић 1982, 1983, 1987). ${ }^{1}$ Ковачевић не говори само о атрибутској употреби прилога уз глаголске именице, него и уз друте врсте именица, тачније уз примарне (Ковачевић $1983)$ или конкретне/предметне именице (Ковачевић 1987) и именичке заменице. У питању су примери као кућа слијева, људи напољу, односно оно јуче, они унутра и слично. Пошто овај рад представља само један сегмент ширег ауторовог истраживања особина глаголских именица, овакви примери нису у центру пажње, иако ће се касније помињати у одређеном контексту, већ само примери у којима су прилозима модификоване глаголске именице.

Примери глаголских именица уз које су употребљени прилози обично се у савременој граматичкој теорији узимају као један од доказа специфичности ове категорије именица, односно њихове повезаности са категоријом глагола. Ако се категорија именица посматра као један континуум који се састоји од различитих класа категорије, онда би на једном крају континуума биле праве именице, са свим прототипичним именичким особинама, а на другом крају би биле глаголске именице, које поред именичких особина, имају и неке особине које су карактеристичне за глаголе. Могућност модификације прилозима била би управо једна таква прототипично глаголска особина.

Овај рад и полази од претпоставке да је модификација прилозима особина глаголских именица која их одваја од типичних именица и покушава да објасни ту њихову специфичност, односно различитост у односу на праве именице. У објашњавању ове карактеристике глаголских именица у савременом српском језику користи се тзв. структурним моделом А. Алексиаду.

${ }^{1}$ Ковачевић наглашава скоро непостојање помена могућности да се именице модификују прилозима, истичући да и тамо где се то штуро помиње користе се ограде типа ријетко или кадито, и наводи неке од аутора који допуштају модификацију именица и прилозима, а не само и искључиво придевима (Ковачевић 1983: 131). 


\section{Структурни модел А. Алексиаду}

А. Алексиаду $(2001,2009)$, позивајући се на запажања код Маранца (1999) и Ембика $(2000,2000 a)$, истиче да се разлике међу класама глаголских именица могу објаснити присуством/одсуством одређених функционалних категорија (односно њихових пројекција) у структури ових именица. Њен приступ покушава да објасни разлике у понашању различитих типова глаголских именица, али се свакако може применити и на разлике међу различитим класама именица генерално, па и међу другим категоријама речи.

Приступ Алексиадуове наставља идеју неотрансформационалиста да разлике међу класама глаголских именица треба објашњавати њиховом различитом синтаксичком структуром, с тим што ту разлику тражи на елементарнијем нивоу структуре, уводећи у анализу глаголских именица функционалне категорије. ${ }^{2}$ Под функционалним (нелексичким) категоријама подразумевају се синтаксичке категорије као што су члан (D), флексија (I), комплементизатор (C), као и неке везане морфеме, попут времена (T), конгруенције (Cgr), броја (Num), или вида (Asp). ${ }^{3}$ Будући да Алексиаду инсистира на структурним разликама међу глаголским именицама, њен приступ је познат и као структурни nрuступ ${ }^{4}$

Идеја се заснива на схватању творбе речи коју је представио Маранц (1999) у оквиру теоријског модела дистрибутивне морфологије (distributed morphology). Према овом моделу творба речи је у потпуности синтаксичке и функционалне природе. Синтаксичке је природе јер је смештена у синтаксичку компоненту граматике. Творба речи нема никакве везе са лексиконом, који је у потпуности искључен из творбених процеса. Творба је по овом моделу функционалне природе јер врста речи која настаје као резултат творбеног процеса зависи од функционалних пројекција у њеној структури. Модел претпоставља да се лексичке одреднице, које нису спецификоване у односу на врсту речи ( $\mathrm{N}$ - именица, V - глагол, А - придев), него постоје као апстрактни корени, приликом творбеног процеса укључују у различита синтаксичка окружења. Да ли ће се одређени апстрактни корен на крају творбеног процеса реализовати

\footnotetext{
${ }^{2}$ Неотрансформационалисти (на првом месту Пикало 1991; Борер 1991, 2003; Берсли и Корнфилт 2000) су сматрали да се неке изразито глаголске карактеристике глаголских именица, као што су присуство аргумената, могућност модификације прилозима и могућност употребе директног објекта у облику акузатива у неким језицима могу објаснити само сличношћу синтаксичке структуре ових именица са синтаксичком структуром глагола. Те глаголске карактеристике глаголских именица су објашњавали присуством VP (verbal phrase = глаголска фраза) чвора у њиховој структури.

${ }^{3}$ Као што лексички центри/категорије (N - именица, $\mathrm{V}$ - глагол, А - придев) имају своје пројекције NP, VP, AP, Џекендоф (1977) је тврдио да и функционалне синтаксичке категорије имају своје пројекције - функционалне пројекције. О функционалним категоријама в. детаљније у Гримшо (2005: 1-73).

${ }^{4}$ Назив се помиње у Алексиаду и Гримшо (2008).
} 
као глагол, именица, или придев, зависи од функционалних слојева који њиме доминирају. Маранц (1999) говори о функционалним категоријама $v, n$ и $a$. Апстрактни корен $(\sqrt{ })$ ступа у односе са функционалним центрима $v, n$, или $a$, реализујући се као глагол, именица, или придев. Уколико се, на пример, апстрактни корен $\sqrt{D E S T R O Y ~ у к љ у ч и ~ у ~ г л а г о л с к о ~ о к р у ж е њ е, ~ п р и м е р ~(1 б), ~}$ добиће се глагол destroy, а ако се укључи у именичко окружење, пример (1в), добиће се (глаголска) именица destruction: ${ }^{5}$

(1) a. $\sqrt{ }=\sqrt{ }$ DESTROY

б.

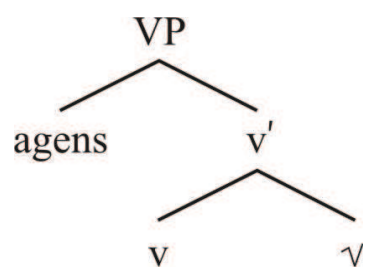

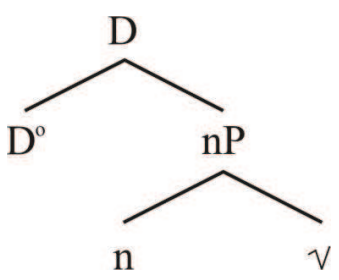

По овом приступу, функционални центри одређују врсту (N, V или A) лексичког центра. Различите лексичке категорије последица су различитог броја и различитих типова функционалних пројекција у оквиру којих се одређени апстрактни корен реализује.

Број и тип функционалних пројекција може да варира и код различитих чланова исте категорије, те због тога ти чланови манифестују различите особине. Такав је према Алексиаду случај и са глаголским именицама. Какве ће карактеристике нека глаголска именица поседовати зависи од именичких и глаголских функционалних пројекција које доминирају одређеним апстрактним лексичким центром, односно од броја и типа тих пројекција. Отуда по А. Алексиаду проистичу разлике између процесуалних (правих) глаголских именица (као што би у српском била именица решавање у примеру Решавање проблема је трајало два дана) и резултативних глаголских именица (као што је именица решење у примеру Решење је у књизи). Код процесуалних именица апстрактним лексичким центром, осим именичких функционалних пројекција, као што су пројекција функционалне категорије броја (Num), или пројекција функционалне категорије конгруенције (Cgr), могу да доминирају и глаголске функционалне пројекције: пројекција функционалне категорије вида (Asp), пројекција категорије стања (St) и пројекција функционалне ка-

${ }^{5}$ У примеру (1) VP означава глаголску фразу, a D је детерминатор. Овде се неће описивати неки теоријски постулати који стоје иза ових дијаграма (стабала), јер то превазилази обим једног оваквог рада. Дијаграми се користе само да би илустровали окружење у које се убацује апстрактни корен који помиње Маранц. 
тегорије $\mathrm{v}$ (такозвано догађајно $v$ - eventive v). ${ }^{6}$ Три последње функционалне категорије (Asp, St u v) нису присутне у структури резултативних глаголских именица. Свакако да ове глаголске функционалне категорије нису присутне ни у структури прототипичних, референцијалних именица, као што су кућа, човек... У структури таквих именица присутне су само типично именичке функционалне категорије и њихове пројекције, које су одговорне, према овом моделу, за прототипичне именичке карактеристике оваквих именица. Са друге стране, у структури глагола, на пример, биле би присутне само прототипичне глаголске функционалне категорије, које су одговорне за прототипичне глаголске карактеристике.

Присуство прилога уз герунд у енглеском језику и уз процесуалне именице у хебрејском, грчком и пољском Алексиаду повезује са присуством АspP (аспектуална/видска фраза, односно пројекција функционалне категорије вида) i StP (стање фраза, односно пројекција функционалне категорије стања) у њиховој структури. Ову претпоставку Алексиаду заснива на радовима Алексиаду (1997) и Ћинкве (1999), где се наводи да је појава прилога уз глаголе такође повезана са присуством одређених функционалних пројекција у структури глагола. Према овој хипотези, присуство аспектуалних (временских) прилога повезано је ca AspP, а присуство прилога за начин ca StP. Генерално, Алексиаду употребу прилога уз глаголске именице објашњава присуством одређених глаголских функционалних пројекција у структури ових именица.

Поставља се питање да ли се употреба прилога уз глаголске именице у савременом српском језику такође може објаснити једним оваквим приступом.

\section{Рефлексија на чињенице из српског}

Овде се наводе примери употребе прилога уз глаголске именице који су екцерпирани из Корпуса савременог српског језика на Математичком факултету у Београду. ${ }^{7}$ У примерима који следе уз глаголске именице су употребљени прилози за место:

Чином сахрањивања обављао се симболични порођај унатраг.

Синдикат захтева да се установи стална и стабилна шема програма, уместо досадашње ад хок, као и да се спречи утицај споља који има све више уплива на РТС.

Током боравка овде, сагледао сам све детаље везане за садржај софтвера и добио прецизну слику о циљној групи којој је намењен , што ће ...

${ }^{6}$ У случају функционалне категорије v, Алексиаду мисли на категорију v коју помиње и Маранц (1999), и која у комбинацији са апстрактним лексичким кореном даје глагол, односно која је под доминацијом VP чвора. Ова категорија имплицира да структура у којој се налази означава догађај - отуда и назив догађајно $v$.

${ }^{7}$ Ови примери се наводе и у Ковачевић 2012. 
Већина људи на хрватској естради рећи ће вам да још није вријеме за долазак овамо, али мислим да ће се то полако мијењати.

Припреме за полазак никуда и ниушта одвијају се на ничијој земљи, тј. у сасвим одговарајућем декору.

Посао мојих колега писаца овде био је да импровизују своју револуцију што је могуће бриљантније, тако да повратак назад не буде могућ.

Ми смо, притиском споља и изнутра, збацили Милошевића и његов режим.

Претња изнутра „Моја је теза”, истиче Линд, „да хуманистичка цивилизација представља релативно младу, глобалну цивилизацију ...

... цио њен вредносно-идеолошки став о смислу тога развоја, упозоривши да се процес цивилизовања одвија у „дугачком низу кретања напред и назад”.

Разне захтеве да се у овој земљи успостави владавина међународног права ми и даље ксенофобично тумачимо као наметање сnоља.

Брз ход узбрдо ме је грејао, али се нисам знојио.

После таквог дана, и још једне предуге вожње назад, била је у стању само да се истушира, умота у баде мантил и завали се поред телевизора са тањиром некаквих гована у крилу ...

Уместо тога, кажу, дочекује их одговор да, пошто суботичка општина не дозвољава њихово настањивање овде, треба да оду на југ Србије.

... жавни и народносни организам, свако време било и остало последње време, јер се стално примичемо граници распарчавања, осипања изнутра а под спољним притиском.

Може се рећи да, као што то примећује и М. Ковачевић (1983: 140) у свом истраживању, неки од ових месних прилога заправо имају начинско значење у овом контексту. Такви би на пример били примери вожња назад, ход узбрдо, порођај унатраг, кретање напред и назад, у којима прилози говоре о начину извођења радње која је обележена глаголском именицом (какво кретање? - кретање напред и слично). Пошто су ови прилози по свом примарном значењу прилози за место, онда се ипак остављају у горњем контексту, заједно са другим месним прилозима.

Као што показују наредни примери, уз глаголске именице могу се употребити и прилози за време:

Најтиражнији румунски лист „Догађај данас" наводи да је у разговорима у Београду договорено да се већ идућег месеца одржи састанак мешовите комисије за...

Поносан сам на рад својих екипа јуче.

То можда не би било опасније него један изостанак увече из Центра.

Због свега реченог, Солдатовићева изложба данас у Београду јесте особен и тренутно најзначајнији културни догађај престоног града, кога ми највероватније нисмо ни свесни.

Предаја докумената и данас и сутра.

Стога су у градској „Топлани” већ од данас приморани на рестрикције (грејање yjympy и увече) док се не повећа доток гаса.

МЕПОР-21 представља идеалну комбинацију са бинокуларним или монокуларним NIGHT VISION системима за осматрање ноћу.

Није свеједно када одлази на спавање, јер спавање дању не може да надокнади оно по ноћи. 
... одговорне за увоз прво индијских, а затим кинеских лекова, за „преливање” лекова, из државних у приватне апотеке, за плаћање унапред појединим фирмама, при чему често нису поштовани ни основни приоритети у лечењу и заштити здравља.

У следећим су примерима уз глаголске именице употребљени прилози за начин:

КСТ се више везао за свирке уживо афирмисаних и неоткривених домаћих и повремено страних рокенрол група и тематске вечери (блуз, хеви метал ...

После избора, председник, потпредседници и министри полажу заклетву читањем $\boldsymbol{\mu a z л а с ~ т е к с т а ~ к о ј и ~ и ~ п о т п и с у ј у ~ и ~ н а к о н ~ т о г а ~ п р е д а ј у ~ п р е д с е д н и к у ~ Н а р о д н е ~ с к у п ш т и н е . ~}$

Своје мишљење о плеј-беку или певању ужсиво демонстрирала је у Задру Радојка Шверко, која је на позорницу изашла без микрофона.

Од помоћи је и слушање музике, певање на страном језику, учење напамет стихова и прозних одломака, будући да се структура језика теже заборавља него реч.

... обичаји предака великом срамотом, кукавичлуком и неизбрисивом подлошћу сматрали су пуцање из потаје, или с леђа, напад изненада и без објаве.

Како се наведени примери из српског језика уклапају у структурни приступ А. Алексиаду, односно да ли овај приступ може да објасни употребу прилога уз глаголске именице у савременом српском језику?

Може се лако претпоставити да је употреба прилога уз глаголске именице у српском језику објашњива присуством одређених прототипично глаголских функционалних категорија у структури ових именица. У овом раду се неће дискутовати о томе које би то функционалне категорије могле бити, али се као логична претпоставка намеће идеја да су то исте функционалне категорије као и у неким другим језицима, категорије о којима говори Алексиаду, вид и стање. Овакве функционалне категорије су присутне у структури глаголских именица, као и у структури глагола, те се уз ове именице, као и уз глаголе, могу употребљавати прилози.

Међутим, проблем за једну овакву претпоставку могу да представљају примери који су поменути на почетку рада. У питању су примери као што су кућа слијева, људи напољу и слични, односно могућност употребе прилога уз праве, конкретне именице у српском језику. Овакви примери су проблем за приступ А. Алексиаду јер према њој прототипичне, референцијалне именице у својој структури садрже само именичке функционалне категорије, без било каквих глаголских функционалних категорија. То даље значи да се уз ове именице као модификатори могу појавити само придеви, а никако и прилози. Како онда објаснити могућност употребе прилога уз конкретне именице у савременом српском језику и да ли примери као кућа слијева, људи напољу и слични урушавају структурни приступ А. Алексиаду, односно да ли онемогућавају његову примену на српски језик?

Примери у којима су прилози употребљени уз конкретне именице суштински се по својој природи разликују од примера у којима су прилози 
употребљени уз глаголске именице. Као илустрација послужиће поређење примера кућа слијева и примера (юихов) долазак овде.

У примеру кућа слијева, јасно је да се ради о кући која се налази слијева. Дакле, ово слијева је настало „скраћивањем” конструкције која се налази слијева. Другим речима, иза прилога слијева стоји релативна реченица која се налази слијева, односно прилог је репрезентант те односне реченице. У оваквим и сличним примерима (у којима је прилог употребљен уз конкретну именицу или именичку заменицу), како то наводи М. Ковачевић, прилог је атрибутску функцију „добио преко атрибутске релативне реченице која је стајала уз ту именицу или замјеницу и унутар које је прилог био или у саставу именског предиката као његов лексички дио, или је имао уз глагол те релативне реченице функцију неке адвербијалне одредбе" (Ковачевић 1983: 133). Отуда се може рећи да прилози уз конкретне именице заправо модификују глагол који је центар односне реченице која модификује конкретну именицу (која је центар целе конструкције). У примеру кућа слијева постоји нешто што се не чује/не чита, а што је подразумевано (овде стављено у заграде): кућа (која се налази) слијева. Прилог слијева овде модификује глагол налазити се.

Са друге стране, у примеру (юихов) долазак овде не постоји ништа што се не чује/не чита, а што је подразумевано. Конструкција је комплетна и не постоји „додатни” глагол који је модификован прилогом. Прилог овде несумњиво директно модификује (глаголску) именицу долазак. Наравно, може се рећи да је ова конструкција, ова именичка синтагма, настала номинализацијом реченице чији је центар глагол долазити: они долазе овде $\rightarrow$ (ъихов) долазак овде. Међутим, овде није потребан никакав други глагол за опис конструкције, као што је то случај са примером кућа слијева (где је потребан глагол налазити ce), јер је „глаголност” садржана у самој (глаголској) именици долазак. На „глаголску природу” конструкције упућује и могућност употребе агенса, овде исказаног присвојном заменицом њихов.

О разлици између примера где су прилози употребљени уз конкретне именице и примера у којима су прилози употребљени уз глаголске именице сведочи и могућност модификације прилозима за начин. Као што показују примери у овом раду, уз глаголске именице, поред месних и временских прилога, могу се употребити и прилози за начин. М. Ковачевић (1983: 140) међутим наводи да се не може са сигурношћу тврдити да се прилози за начин могу користити и уз конкретне именице, већ да су искључиво карактеристични за модификацију глаголских именица.

Уколико се има у виду представљена разлика између примера у којима су прилози употребљени уз конкретне именице и примера у којима су прилози употребљени уз глаголске именице, може се рећи да се чињенице из српског језика уклапају у структурни модел А. Алексиаду. Примери као кућа слијева, 
у којима су прилозима модификоване конкретне именице, по својој природи се суштински разликују од примера у којима су прилозима модификоване глаголске именице, и као такви не представљају проблем за структурни модел А. Алексиаду. Може се претпоставити да се у структури глаголских именица у савременом српском језику налазе одређене функционалне категорије (попут функционалне категорије вида или стања) које су одговорне за појаву прилога Уз ове именице.

\section{ЗАКљУЧАК}

Истраживање је показало да иако се и уз конкретне и уз глаголске именице у савременом српском језику могу употребити прилози, између примера где су прилозима модификоване конкретне именице и примера у којима су прилозима модификоване глаголске именице постоји суштинска разлика. Само у случају глаголских именица, директно је именица модификована прилогом. У случају конкретних именица, увек у структури именичке синтагме чији је конкретна именица центар фигурира релативна реченица, односно постоји глагол који је центар те реченице. У таквим примерима заправо је тај глагол директно модификован прилогом, а не конкретна именица.

Ово даље значи да се употреба прилога уз глаголске именице у савременом српском језику може објаснити структурним моделом А. Алексиаду, односно да се може претпоставити да су за појаву прилога уз глаголске именице одговорне одређене изразито глаголске функционалне категорије у структури тих именица. Те именице, у својој структури, поред типично именичких функционалних категорија, имају (попут глагола) и неке типично глаголске функционалне категорије (као што су на пример вид или стање). Управо су ове категорије разлог да се глаголске именице, поред придева, могу модификовати и прилозима.

Задатак неких будућих истраживања могло би бити тачно утврђивање врсте и броја функционалних категорија које се налазе у структури глаголских именица и које одређују њихову модификацију прилозима, а и неке друге типично глаголске карактеристике, као што је на пример аргументска структура ових именица. 


\section{ЛИТЕРАТУРА}

Алексиаду 1997: A. Alexiadou, Adverb Placement: a Case Study in Antisymmetric Syntax, Amsterdam: John Benjamins.

Алексиаду 2001: A. Alexiadou, Functional Structure in Nominals: Nominalization and Ergativity. Amsterdam/Philadelphia: John Benjamins Publishing Company.

Алексиаду 2009: A. Alexiadou, On the role of syntactic locality in morphological processes: the case of (Greek) derived nominals, A. Giannakidou \& M. Rathert (ed.) Quantification, definiteness and nominalization, 253-280. Oxford: Oxford University Press. http://ifla.uni-stuttgart. de/institut/mitarbeiter/artemis/ artemissaabrrev.pdf

Алексиаду и Гримшо 2008: A. Alexiadou \& J. Grimshaw, Verbs, nouns and affixation, F. Schäfer (ed.) Working Papers of the SFB 732 Incremental Specification in Context, 1-16. http://elib.uni-stuttgart.de/opus/volltexte/2008/3545/pdf/SinSpeC1_1_

Берсли и Корнфилт 2000: R. Borsley \& J. Kornfilt, Mixed extended projections, Borsley, R. (Ed.) Syntax and Semantics 22: The Nature and Function of Syntactic Categories, Academic Press, New York, 101-131.

Борер 1991: H. Borer, The Causative-Inchoative Alternation: A Case Study in Parallel Morphology, The Linguistic Review 8, 119-158.

Борер 2003: H. Borer, Exo-skeletal vs. endo-skeletal explanations: syntactic projections and the lexicon, Polinsky, M. and J. Moore, eds. Explanation in Linguistic Theory, Stanford: CSLI.

Гримшо 2005: J. Grimshaw, Words and Structure, Standford: Center for the Study of Language and Information.

Ембик 2000: D. Embick, Features, Syntax and Categories in the Latin Perfect, Linguistic Inquiry 31, 185-230.

Ембик 2000a: D. Embick, Participial Structures and Participial Asymmetries, Massachusetts Institute of Technology.

Ковачевић 2012: Борко Ковачевић, Синтаксичко-семантичке категорије глаголских имениияа, докторска дисертација, Филолошки факултет у Београду.

Ковачевић 1982: Милош Ковачевић, Типови неконгруентних атрибута уз девербативне именице у дјелима Анђелка Вулетића, Књижевни језик 11/2, Сарајево, 81-92. 
Ковачевић 1983: Милош Ковачевић, Атрибутска употреба прилога у српскохрватском језику, Зборник за филологију и лингвистику XXVI/1, Нови Сад, 131-145.

Ковачевић 1987: Милош Ковачевић, Семантички типови неконгруентних атрибута српскохрватског језика, Југословенски семинар за стране слависте 37, Нови Сад, 119-134.

Маранц 1999: A. Marantz, Creating words above and below little v, Massachusetts Institute of Technology.

Пикало 1991: C. Picallo, Nominals and Nominalizations in Catalan, Probus 3/3, 271-316.

һинкве 1999: G. Cinque, Adverbs and Functional Heads, Oxford: Oxford University Press.

Џекендоф 1977: R. Jackendoff, X-Bar Syntax: A Study of Phrase Structure, Mass.: MIT Press.

\section{ON DEVERBAL NOUNS MODIFIED BY ADVERBS IN SERBIAN}

\section{Summary}

The paper discusses some examples from Serbian where deverbal nouns are modified by adverbs. These adverbs can be adverbs for place, adverbs for time, and manner adverbs. It has been shown that the examples where adverbs modify deverbal nouns crucially differ from the examples where adverbs modify concrete nouns. Only in the case of the modification of a deverbal noun adverbs directly modify the noun. However, in the case of concrete nouns, adverbs are just represents of a relative clause, and they directly modify a verb which is the center of the relative clause.

The fact that deverbal nouns in Serbian can be modified by adverbs, not just by adjectives, could be explained by the structural approach created by A. Alexiadou. According to this approach some typical verbal functional categories like aspect or voice in the structure of deverbal nouns are responsible for the possibility of their modification by adverbs.

Key words: Serbian, adverb, deverbal nouns, functional category 